\title{
Attitude of Loan Officers in Affordable Housing Finance Companies towards Low-Income Customers in Central India
}

\author{
Manav Khaire \\ Research Scholar, Centre for Policy Studies, IIT Bombay, Powai, Mumbai - 400076 \\ Email:manav_k@iitb.ac.in
}

Received: $20^{\text {th }}$ September 2018, Accepted: $11^{\text {th }}$ October 2018, Published: $31^{\text {st }}$ October 2018

\begin{abstract}
The access to finance for the low-income households is severely constrained by the operational and institutional factors of mainstream finance institutions such as banks and large housing finance companies (HFCs) in India. These factors have greater effect on the access of unbanked population to housing finance as it includes large amount of money for a longer tenure thereby increasing the risk associated with the credit. The institutions engaged into dealing with such credit risk face the challenge of information asymmetry which is tackled by these institutions at various levels during the credit underwriting of a particular application. The first level of this screening and underwriting process involves interaction of the field employees of the institutions who act as first level loan officer for an application. The role of first level loan officer gets easier while screening the application of high-income and middle-income borrowers, as these customers possesses the required documents. But, in the case of the low-income households engaged in informal sector, they don't possess the required documents and have volatile incomes, as a result, the credit assessment becomes challenging. The role of the first level loan officers becomes imperative in these types of cases where the applicants do not fit the regular documentation criterion. In this study, we attempt to investigate the attitudes of the loan Officers of select Affordable HFCs (AHFCs) towards the low-income household customers. The study presents a descriptive analysis of attitudes of the loan officers belonging to select AHFCs in the Nagpur region in Maharashtra. The results of the study indicate that the loan officers carry a positive attitude towards poverty. The result can be seen as a contribution towards research in the area of investigating attitudinal constraints and its effects on the poor.
\end{abstract}

\section{Keywords}

India, Affordable Housing Finance Companies, Financial Exclusion, Attitude towards Poor

\section{Introduction}

The concept of access to finance is operationalized on the basis of dimensions of financial inclusion and financial exclusion. As per World Bank, financial inclusion is defined as a condition wherein the individuals and businesses have access to useful and affordable financial products and services that meet their needs - transactions, payments, savings, credit and insurance - delivered in a responsible and sustainable way [1]. There is no universally accepted definition for measurement of financial inclusion which makes it difficult to measure. Hence, in order to measure access to finance, the financial exclusion dimension is measured which has been defined in literature and has a widespread use. Financial exclusion is defined as "those processes that serve to prevent certain social groups and individuals from gaining access to the financial system" [2]. The other definitions of financial exclusion attempt at narrowing the applicability of the concept, Meadows et al. (2004) defines it as "the potential difficulties faced by some segments of population in accessing mainstream financial services such as bank accounts/home insurance" [3]. Rogaly (1999) defines financial exclusion as "exclusion from particular sources of credit and other financial services including insurance, bill-payment services and accessible and appropriate deposit accounts" [4]. While studying the concept of financial exclusion, two studies by Dymski (2005) and Carbo et al. (2007) respectively have found that the financial institutional structure has led to the financial exclusion of poorer sections of the society in the context of European countries [5] [6]. In Indian context, the financial inclusion is defined as by Dev (2006) as "delivery of banking services at an afford-able cost to the vast sections of disadvantaged and low-income group" [7]. Pal \& Pal studied the income-related inequality in financial inclusion in India within the framework of role of banks. The paper concluded that even though the financial exclusion problem is present across all the households, the poor households are at a greater risk of getting excluded [8].

In the backdrop of above literature around the issue of access to finance, the status of unbanked population (without an account at a financial institution or through a mobile money provider) in the world can be seen as a leading indicator of financial exclusion. As per the Global Findex Database 2017 report by World Bank Group, 1.7 billion adults remain unbanked and almost all of these belong to developing countries. The report also states that nearly half 
of the unbanked population live in just seven developing economies: Bangladesh, China, India, Indonesia, Mexico, Nigeria, and Pakistan wherein the majority of unbanked people belong to poorer section of the society [9].

The financial markets in developing economies face challenge of information asymmetry ${ }^{1}$ which gives rise to problems with adverse selection and moral hazard and consequently problems with screening, monitoring and enforcement with respect lending to the clients. This challenge of asymmetric information is intensified in the case of lower income households as they often lack formal forms of collateral, such as land or property, thereby increasing the transaction cost, and hence get excluded from formal financial institutions [10]. The UN-Habitat (2008) report has stated six reasons for exclusion of poor from formal financial institutions. The poor are excluded because they (formal financial institution) (1) require to have bank accounts with minimum deposits, discourage small, regular deposits from poor clients; (2) charge high fees; (3) financial institutions are located outside the areas where the poor live and increase the travel cost for the poor to access such services; (4) the poor do not have formal legal titles to provide collateral security as required by formal financial institutions; (5) the poor do not have capacity to make monthly repayment over a long period; (6) the poor often do not have formal employment. Therefore the formal financial institutions fail to provide financial services to the low-income sector [11]. Given the premise that the poor and low-income borrowers face constraints leading to their exclusion from accessing formal finance, we propose to investigate this financial exclusion in case of housing finance.

\section{Background of the Study}

There are different definitions of housing finance given by different scholars, out of them, one simplistic definition is given by King (2009) "housing finance is what allows for the production and consumption of housing. It refers to the money we use to build and maintain the nation's housing stock. But it also refers to the money we need to pay for it, in the form of rents, mortgage loans and repayments" [12]. In India, the housing finance includes primary lending institutions viz. Scheduled Commercial Banks (SCBs), Housing Finance Companies (HFCs), Apex Cooperative Housing Federations (ACHFs), and other Non-banking Finance Companies, Microfinance Institutions (MFIs). The market is dominated by SCBs $(60 \%)$ and HFCs $(39.5 \%)$ while the rest of the players contribute less than $0.5 \%$ of the market share [13]. The National Housing Bank (NHB) is the apex institution for regulating and controlling the HFCs in India. The yearly reports on the progress of housing finance sector by NHB has documented a sizeable growth in the housing finance market measured in terms of total housing loan outstanding which stood at INR 10.63 trillion (US\$ 147 billion) as on March 2016. But, over a period of time the total housing loan portfolio has experienced a shift towards higher ticket slab which means the lending institutions are giving out less lower ticket size (affordable housing) loans (less than INR 1.5 million i.e. US4 20838) and the market activity in the lower ticket size is considerably reduced [13]. This has created a demand-supply gap in housing finance market in the affordable housing space (less than INR 1.5 million i.e. US\$20838). This gap is being targeted by new entrants which are also referred as Affordable Housing Finance Companies (AHFCs) which are nothing but HFCs but with loan size less than INR 50 billion (US\$ 0.69 billion) and specific focus on affordable housing loans and lower income segment borrowers [14].

The AHFCs in India targets particularly low-income segment in India which is seen as a high risk segment by SCBs and HFCs. A study by FSG India has documented that the AHFCs have been successful in meeting demand of informal sector low income customers by growing to an exceptional level [from INR 10 billion (US\$ 148 million) in March 2013 to INR 270 billion (US\$ 4 billion) in December 2017] with their innovative field-based, detailed credit assessment and verification process [15]. The study concludes that the AHFCs have been instrumental in enabling the access to housing finance with the use of innovative field based credit assessment and reorienting focus of their business towards lower income group segment households in India.

\section{Results and Discussion}

The Reserve Bank of India identified the supply and demand side challenges faced in the context of financial inclusion especially in the case of the poor borrowers. On the supply side i.e. from the side of financial institutions, one of the identified factors is the attitude of the staff [16]. Even in the case of AHFCs, the frontline credit officers come across the low income borrowers on a daily basis and perform the job of initial screening of the applicants. In this case the attitude of the staff of the AHFCs comes into the picture while dealing with the potential customers belonging to lower income segment. In India, the lower income segment is constitutes of a large population and

\footnotetext{
${ }^{1}$ There are two main problems described in the literature for information asymmetry: adverse selection and moral risk. The first involves the creditor's lack of knowledge in relation to type of borrower, that is, the lender does not know how risk inclined is the borrower, how honest, how responsible, etc. On the other hand, moral risk involves the lender's lack of information regarding the type of action the borrower can have. In this particular case, in relation to what the borrower will do with the loan, what type of investment he/she will choose.
} 
comprises of 206 million households ( $85.8 \%$ of total population) with annual income less than INR 0.3 million (US\$ 4167) [17]. The outreach of the HFCs and SCBs gets constrained as a result of lack of incentive and high risk of lending towards this segment. In Indian context, Jones et al undertook a study to analyse attitudes and behaviour of rural bank managers in Madhya Pradesh, and found that perception of risk reduces their lending to low income clients: "a number of managers indicated that their own worries about risk and repayment negatively impact their lending to the poor" [18].

We propose to study the attitude of loan officers in AHFCs in central Maharashtra region in India. There are 71 HFCs in India, out of which 55 are identified as AHFCs which cater specifically to lower income segment. Maharashtra is leading in the affordable housing sector constituting $50 \%$ of the portfolio in the affordable housing segment, and the top three states (Gujarat and Rajasthan, apart from Maharashtra) comprising 64 per cent of the total lending in the affordable segment. In Nagpur region, 8 AHFCs have their presence either with a direct office or operating through a franchise. We contacted 8 AHFCs out of which four AHFCs responded positively for allowing us to administer the survey amongst their loan officers. We identified 35 respondents from four AHFCs and sent out the questionnaire to all of them, out of which we got 20 responses.

The attitudinal questions are about subjective psychological state including evaluative component and are not verifiable by external observation and records. In a broader sense, the definition of attitude is given as "a psychological tendency that is expressed by evaluating a particular entity with some degree of favour or disfavour" [19]. In order to measure the attitude towards poverty, Atherton et al. (1993) provided a 37-item Likert-type scale that assesses attitude toward poverty and poor people [20]. We make use of a short form of this Attitude Towards Poverty and Poor (ATP) scale containing 21-item Likert-type scale developed by Yun and Weaver (2010) to measure the attitude of loan officers towards lo income customers in selected geographical region [21]. The 21-item ATP scale utilizes items that load across three factors: personal deficiency, stigma, and structural perspective. The three factors are intended to measure a range of diverse attitudes toward poverty and poor people: personal deficiency ( 7 items. e.g., "Poor people are dishonest"); stigma ( 8 items. e.g. "Children raised on welfare will never amount to anything"); and structural perspective (6 items. e.g., "I would support a program that resulted in higher taxes to support social programs for poor people"). Individual responses are indicative of the degree to which respondents' attitudes favour personal or structural perspectives or support stigmatization of poor. Respondents express agreement or disagreement with each statement by using a five point Likert-type scale: $\mathrm{SA}=$ strongly agree (1), $\mathrm{A}=$ agree (2), $\mathrm{N}=$ neutral (3), $\mathrm{D}=$ disagree (4), $\mathrm{SD}$ = strongly disagree (5). Scoring of the scale is such that the higher the score, the more favourable the respondents' attitude toward the poor [21]. Demographic data collected included gender, age, marital status, number of children (if married), number of dependents, years of work experience, and annual income. The total number of female respondents was $3(15 \%)$ and number of male respondents was 17 (75\%). The respondents reported ages ranged from 26 to 42, with a mean of 32 for the overall sample. The respondents reported work experience ranged from 1 to 10 years, with a mean of 5.46 years for the overall sample. The respondents reported number of dependents ranged from 1 to 5, with a mean of number of dependents as 2.2 for the overall sample.

The overall ATP scale measures poverty attitudes that produce a score from 21 to 10 . The higher scores represent a more positive attitude toward poor and lower scores representing lower attitude toward poor. The overall mean score on the survey for the respondents were 72.15 and the standard deviation was 3.392. The item that received the highest level of agreement from respondents was item 12, "An able bodied person using welfare is ripping off the system" $(\mathrm{M}=4.60)(\mathrm{SD}=0.503)$. The item that received the second highest agreement from respondents was item 1 "poor people are different from the rest of the society" $(\mathrm{M}=4.10)(\mathrm{SD}=.553)$. Both of these items reflected "very positive" attitudes toward poverty. The item with the lowest level of agreement was item 17, "I would support a program that resulted in higher taxes to support social programs for poor people" $(\mathrm{M}=2.85)(\mathrm{SD}=0.587)$. This item reflects a negative attitudes toward poverty score, reverse scoring means this is a "disagree" on the interpretive score (items 16-21 were reverse scored). Overall, the responses to items fell within the "positive range" or strongly disagree of the interpretive scale which indicated positive attitudes of poverty.

\section{Conclusion}

The purpose of this research study was to explore the attitudes and beliefs that the loan officers of AHFCs hold towards poverty and individuals living in poverty. Attitude towards poverty (ATP) scale developed by Yun and Weaver (2010) was used to investigate into the topic, a significant finding indicated that loan officers held positive attitude towards poor. This result can be considered as a positive indicator which shows that the loan officers have an empathetic attitude towards poor which is an enabler within the context of financial inclusion paradigm. However, the replication of the ATP scale in Indian context may report incorrect results as the questions of the ATP scale are designed in the context of the welfare state of developed nations. A detailed study with a larger sample 
suitable for Indian context can be undertaken to investigate the attitudinal phenomenon amongst loan officers with respect to poor customers. This may throw up some conclusions which may be used for developing a training manual dedicated towards addressing the financial exclusion challenge for India.

\section{References}

[1] World Bank, Understanding financial inclusion (2018) Available at https://www.worldbank.org/en/topic/financialinclusion/overview (accessed 18 September 2018).

[2] Leyshon, A., \& Thrift, N. (1995). Geographies of financial exclusion: financial abandonment in Britain and the United States. Transactions of the Institute of British Geographers, 312-341.

[3] Meadows, P., Ormerod, P., \& Cook, W. (2004). Social networks: their role in access to financial services in Britain. National Institute Economic Review, 189(1), 99-109.

[4] Rogaly, B. (1999). Poverty and social exclusion in Britain: Where finance fits. Poverty, Social exclusion and microfinance in Britain. Oxford: Oxfam GB.

[5] Dymski, G. (2005) Banking Strategy and Financial Exclusion: Tracing the Pathways of Globalization. Revista de Economia, Vol. 31, No. 1-29, pp. 107-143.

[6] Carbo, S., Gardener, E. P., \& Molyneux, P. (2007). Financial exclusion in Europe. Public Money and Management, 27(1), 21-27.

[7] Dev, S. M. (2006). Financial inclusion: Issues and challenges. Economic and political weekly, 4310-4313.

[8] Pal, R., \& Pal, R. (2014). Income related inequality in financial inclusion and role of banks: evidence on financial exclusion in India. Available at http://oii.igidr.ac.in:8080/xmlui/bitstream/handle/2275/261/WP-2012013.pdf? sequence=1\&isAllowed=y (accessed 18 September 2018).

[9] Demirguc-Kunt, A., Klapper, L., Singer, D., Ansar, S., \& Hess, J. (2018). The Global Findex Database 2017: Measuring Financial Inclusion and the Fintech Revolution. The World Bank.

[10] Ghosh, S., \& Van Tassel, E. (2013). Funding microfinance under asymmetric information. Journal of Development Economics, 101, 8-15.

[11] Zhang, X. Q. (2008). Housing for All: The Challenges of Affordability, Accessibility, and Sustainability: the Experiences, and Instruments for the Developing and Developed Worlds: a Synthesis Report. Un-habitat.

[12] King, P. (2009). Understanding Housing Finance: Meeting needs and making choices. Routledge.

[13] National Housing Bank, Report on Trend \& Progress of Housing in India (2016), Available at https://nhb.org.in/wp-content/uploads/2018/02/T\%20\&\%20P\%202016.pdf (accessed 18 September 2018).

[14] CRISIL, Affordable homes altering mortgage market dynamics (2017). Available at https:/www.crisil.com/content/dam/crisil/our-analysis/reports/Ratings/documents/CRISIL-Ratings-affordable-

homes-altering-mortgage-market-dynamics-May2017.pdf (accessed 18 September 2018).

[15] FSG India, State of the low income housing finance market in India 2018 (2018). Available at http://ficci.in/spdocument/22983/State\%20of\%20the\%20Low-Income\%20Housing\%20Market\%20-

\%20High\%20Res\%20wo\%20press\%20marks\%20-\%2005-14....pdf (accessed 18 September 2018).

[16] Reserve Bank of India, Roundtable on the updates on Financial education and Inclusion programs in India (2011). Available at https://www.oecd.org/finance/financial-education/48303408.pdf (accessed 18 September 2018).

[17] Ablett, J., Baijal, A., Beinhocker, E., Bose, A., Farrell, D., Gersch, U., Greenberg, E., Gupta, Sh. \& Gupta, S. (2007) The 'bird of gold': The rise of India's consumer market, McKinsey Global Institute.

[18] Jones, J. H. M., Williams, M., Nilsson, E., \& Thorat, Y. (2007). Training to address attitudes and behaviour of rural bank managers in Madhya Pradesh, India: a programme to facilitate financial inclusion. Journal of International Development: The Journal of the Development Studies Association, 19(6), 841-851.

[19] Eagly, A. H., \& Chaiken, S. (2007). The advantages of an inclusive definition of attitude. Social cognition, 25(5), 582-602.

[20] Atherton, C. R., Gemmel, R. J., Haagenstad, S., Holt, D. J., Jensen, L. A., O’Hara, D. F., \& Rehner, T. A. (1993, December). Measuring attitudes toward poverty: A new scale. In Social Work Research and Abstracts (Vol. 29, pp. 28-28). NATIONAL ASSOCIATION OF SOCIAL WORKERS.

[21] Yun, S. H., \& Weaver, R. D. (2010). Development and validation of a short form of the attitude toward poverty scale. Advances in Social Work, 11(2), 174-187. 